\title{
Direct Evidence for Bottom-fishing in Archaeological Whelks (Buccinum undatum)
}

\section{Greg Campbell ${ }^{1}$ and Michael Russell ${ }^{2}$}

Cite this as: Campbell, G. and Russell, M. (2014). Direct Evidence for Bottom-fishing in Archaeological Whelks (Buccinum undatum) 'Human Exploitation of Aquatic Landscapes' special issue (ed. Ricardo Fernandes and John Meadows), Internet Archaeology. doi:10.11141/ia.37.6

1. The Naive Chemist. 150 Essex Road, Southsea, Portsmouth PO4 8DJ, UK.

Email: g.v.campbell@btinternet.com

2. English Heritage, Fort Cumberland, Eastney, Portsmouth PO4 9LD, UK.

Keywords: Whelks, Buccinum, archaeology, diagnostic shell damage, bottom-fishery

This issue has been funded by the Graduate School "Human Development in Landscapes", University of Kiel with additional funding from the Institute for Ecosystem Research, University of Kiel and the Centre for Baltic and Scandinavian Archaeology, Schloss Gottorf.

(C) Author(s). Except where otherwise noted, content from this work may be used under the terms of the Creative Commons Attribution 3.0 Unported licence, which permits unrestricted use, distribution, and reproduction in any medium, provided that attribution to the author(s), the title of the work, the Internet Archaeology journal and the relevant URL/DOI is given. 



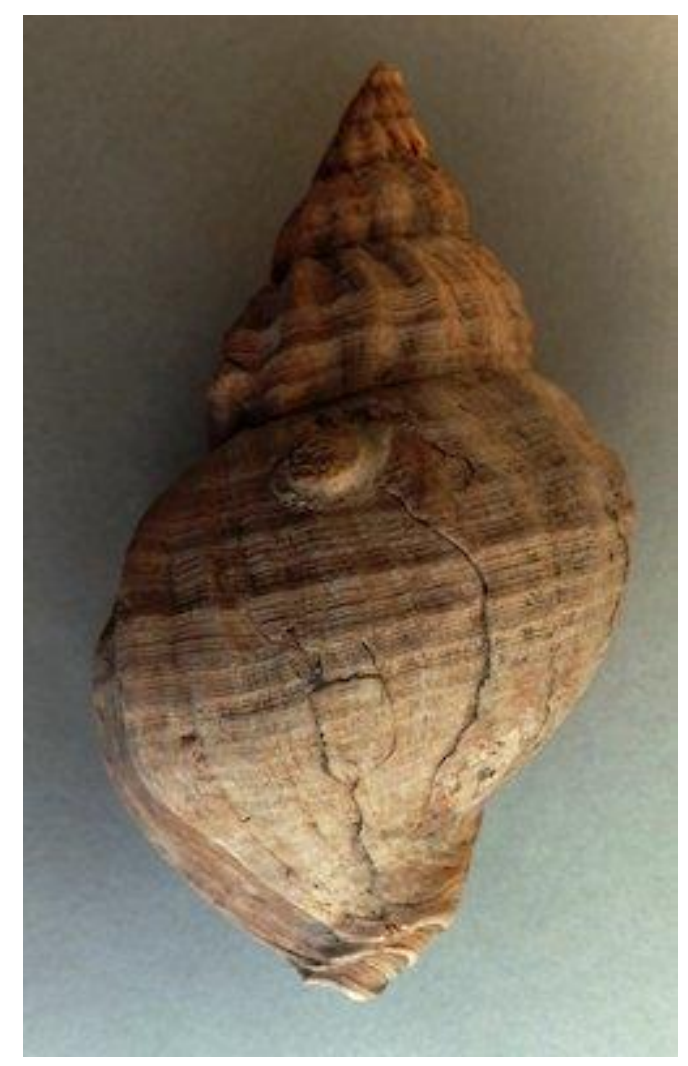

Bottom-fishing is a major step in the increase of exploitation of marine resources, requiring specialised craft, technology, and practitioners. However, the onset and development of bottom-fishing is almost impossible to observe directly in the archaeological record, and is usually reconstructed by implication. The shells of common whelk (Buccinum undatum) from a kitchen midden at Carisbrooke Castle, Isle of Wight, southern England, showed a pattern of damage characteristic of harvesting by bottom-fishing, rather than the usual baited pots. Some whelks had survived being dredged several times. The very consistent size-shape relationship made it likely the whelks were all from a single habitat, probably in the fast tidal flows typical of the oyster-beds just north of the island. The whelks were harvested along with oysters: the whelks' shells were encrusted in a similar way to the oysters in the same midden, and the whelks even bore sub-adult oysters (spat), despite these being potential prey for whelks. This may be the first time whelks have been shown to have been harvested along with oysters and also seems the first direct evidence for a bottom-fishery for whelks. 


\section{List of Figures}

Figure 1: Shell of common whelk, Buccinum undatum L. ap: aperture; $b w$ : body-whorl; $c n$ : siphonal canal; Ip: lip of aperture; $s p$ : spire. (Image credit: amended from Dautzenberg and Fischer 1912, pl. 4)

Figure 2: Types of bottom-fishing gear. (a): bottom-trawl of beam-type (b): dredge. (Image credit: after Nédélec and Prado 1990)

Figure 3: Location of the Isle of Wight, Carisbrooke Castle, and its Privy Garden.

(a): Britain and north-west France, showing location of Isle of Wight (b), England (E); Ireland (I); France (Fr); Scotland (S); Wales (W).

(b): Isle of Wight, showing location of Carisbrooke Castle (c.)

(c): Carisbrooke Castle with motte (m.) and Privy Gardens (p.g.)

Figure 4: Dimensions (in $\mathrm{mm}$ ) measured on the intact whelks ( $B$. undatum) in midden 7325 at Carisbrooke. $\mathrm{H}$ : shell height; Hap: aperture height; W: shell width; Wap: aperture width. (Image credit: after Thomas and Himmelman (1988).

Figure 5: Distribution of shell height in the whelks from midden 7325 (N: 48).

Figure 6: Variation of shell shape (height-width ratio, H/W) with shell size (shell height, $\mathrm{H}$ ) in the whelks in midden 7325 (N: 36). Line: linear regression fitted by o.l.s.

Figure 7: Relationship, with the estimated width values, of the residuals (estimated value, minus true value) in estimating shell width with the allometric formula for shell width derived for the whelks in midden 7325 (a 'versus plot') ( $\mathrm{N}$ : 36). Line: linear regression fitted by o.l.s.

Figure 8: Relationship of aperture shape (Hap/Wap) with size (shell height) in the whelks from midden 7325 ( $\mathrm{N}: 36)$; aperture shape does not change with shell size (cf. Figure 6). Line: linear regression fitted by o.l.s.

Figure 9: Examples of types of damage observed in archaeological whelk shells from Carisbrooke midden 7325 (a, c, e, g) and analogous damage in whelks beam-trawled from regularly trawled North Sea whelk beds ( $b$, 
d, f, h; modified from figs 1 and 4 of Mensink et al. 2000). (a),(b): slight damage (growth-check to lip); (c),(d): moderate damage; (e),(f): severe damage to back of body-whorl; $(\mathrm{g}),(\mathrm{h})$ : detail of spire showing repaired moderate or severe damage. Scale bar: $10 \mathrm{~mm}$.

Figure 10: Examples of biological infestation of whelks from Carisbrooke midden 7325. (a): burrow of serpulid worm Polydora ciliata; (b): calcareous byssus from attachment of saddle-oyster Anomia ephippium; (c): linear pattern of surface perforations from the sponge Cliona; (d): lower valve of juvenile oyster Ostrea edulis ('spat'). Scale bar: $10 \mathrm{~mm}$.

\section{Introduction}

Putting to sea to fish has been a way of life and an important economic activity for millennia (e.g. Robinson 2013). However, archaeological evidence for specific types of offshore marine fishing is uncommon: the objects and vessels used were usually lost at sea or salvaged and reused, and most of their components were organic and therefore have not survived (Beltrame 2010). Once-common kinds of fishing vessel have completely disappeared, leaving no historical description or archaeological trace (e.g. Hutchinson 1994, 142). Also, the technology employed in the past to fish for a particular catch almost never left direct physical marks on that catch, but has to be inferred from the size and habitat of the catch (Morales Muniz 2010; e.g. Barrett et al. 2004). The methods for drawing these inferences are quite developed for archaeological remains of consumed shellfish (Campbell 2008; e.g. Cabral and da Silva 2003; Kent 1992).

The common whelk, edible whelk or buckie (Buccinum undatum L., 1758) is one of the consumed shellfish found archaeologically. It is a marine gastropod of the cold North Atlantic (Hayward and Ryland 1995, 685-86); its shell is large (up to $165 \mathrm{~mm}$ : Jeffreys 1867, 287), spiral, and sharply conical, with a prominent, open siphonal canal at its base and a distinctive undulating surface with fine spiral ribs (Figure 1). Whelks are highly mobile carnivore-scavengers found across all types of sea-bed, from the low inter-tidal to deeper coastal waters (Fretter and Graham 1962, 517- 
19) down to $1200 \mathrm{~m}$ (Hayward and Ryland 1995, 686), but usually in waters between $15 \mathrm{~m}$ and $30 \mathrm{~m}$ deep (Valentinsson et al. 1999).

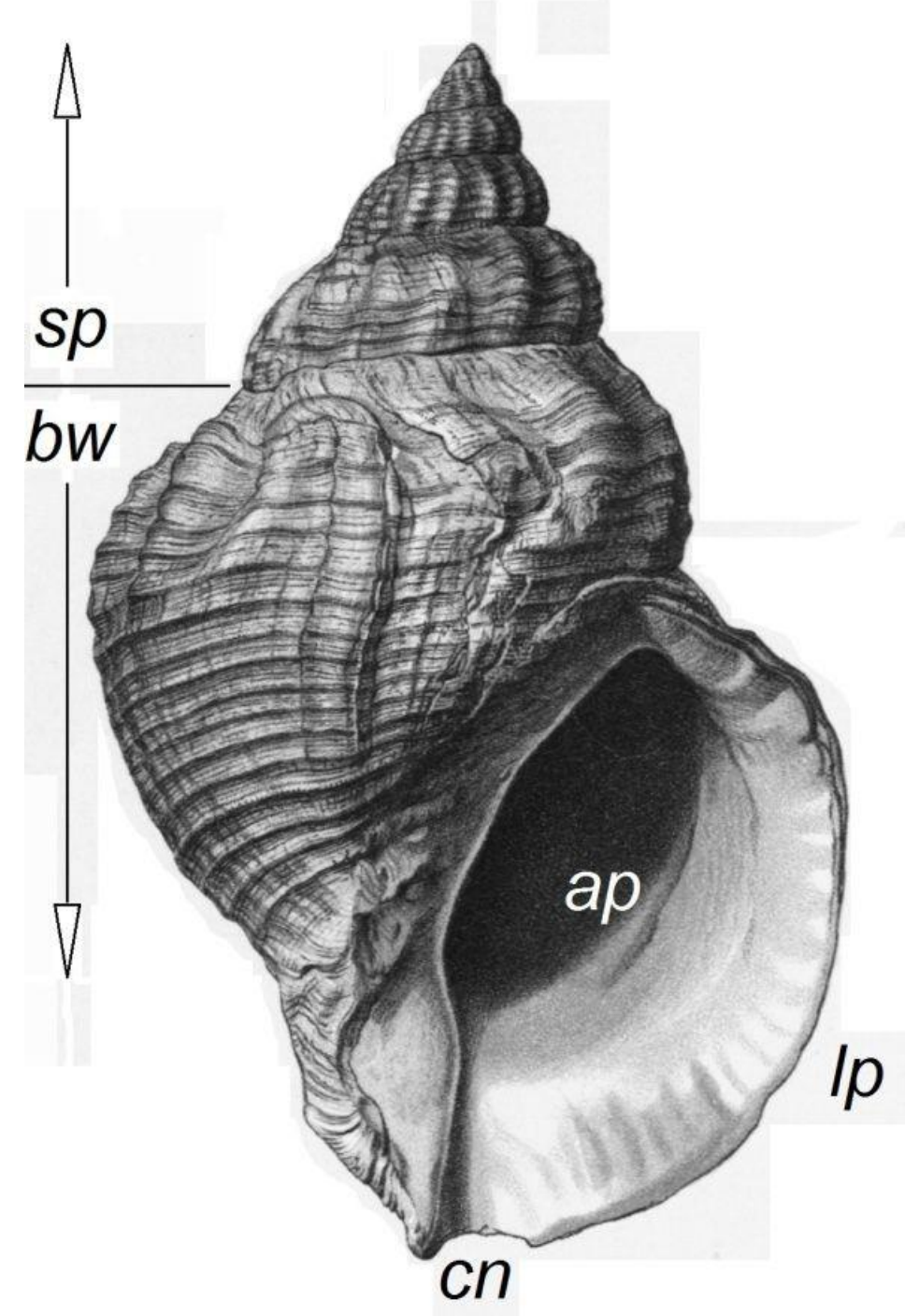

Figure 1: Shell of common whelk, Buccinum undatum L. ap: aperture; bw: body-whorl; $c n$ : siphonal canal; Ip: lip of aperture; sp: spire. (Image credit: amended from Dautzenberg and Fischer 1912, pl.

4)

Whelks can be fished by both methods of bottom-fishing, bottom-trawling (Mensink et al. 2000) and dredging (Hancock 1967, 4). In bottomtrawling, a roughly conical net, with its open end weighted and held open by some structure such as a wooden or metal beam (Figure 2a), is dragged ('trawled') behind a vessel along the surface of the sea-bed (Nédélec and Prado 1990, 25). In dredging, the structure holding the net open includes a bar at its base (Figure $2 b$ ) that scrapes the sea-bed (Nédélec and Prado 1990, 31). Dredging seems to be the older method, employed principally for oysters. Oyster-shells with shapes characteristic 
of uncrowded dredged beds, not natural reefs, are usual in Saxon (Winder and Gerber-Parfitt 2003), Roman (Winder 1985, 93) and prehistoric deposits (Milner 2002). Oyster-dredging has been regulated and taxed in England since the 12th century AD (Eyton 1858, 4). Bottom-trawls seem to have developed later; a Royal Commission was set up to investigate their introduction to England in AD 1376 (Engelhard 2008, 2). Bottomfishing requires boats designed specifically for power, stability and sailing a steady course, and equipped with specialised gear for raising, lowering and surviving the dragging of heavy nets, and with a crew who know how to work that gear (McKee 1983, 40-41; Rawson and Tupper 2001, 689); its onset marks the emergence of a specialised marine fishing technology from general-purpose fishing.

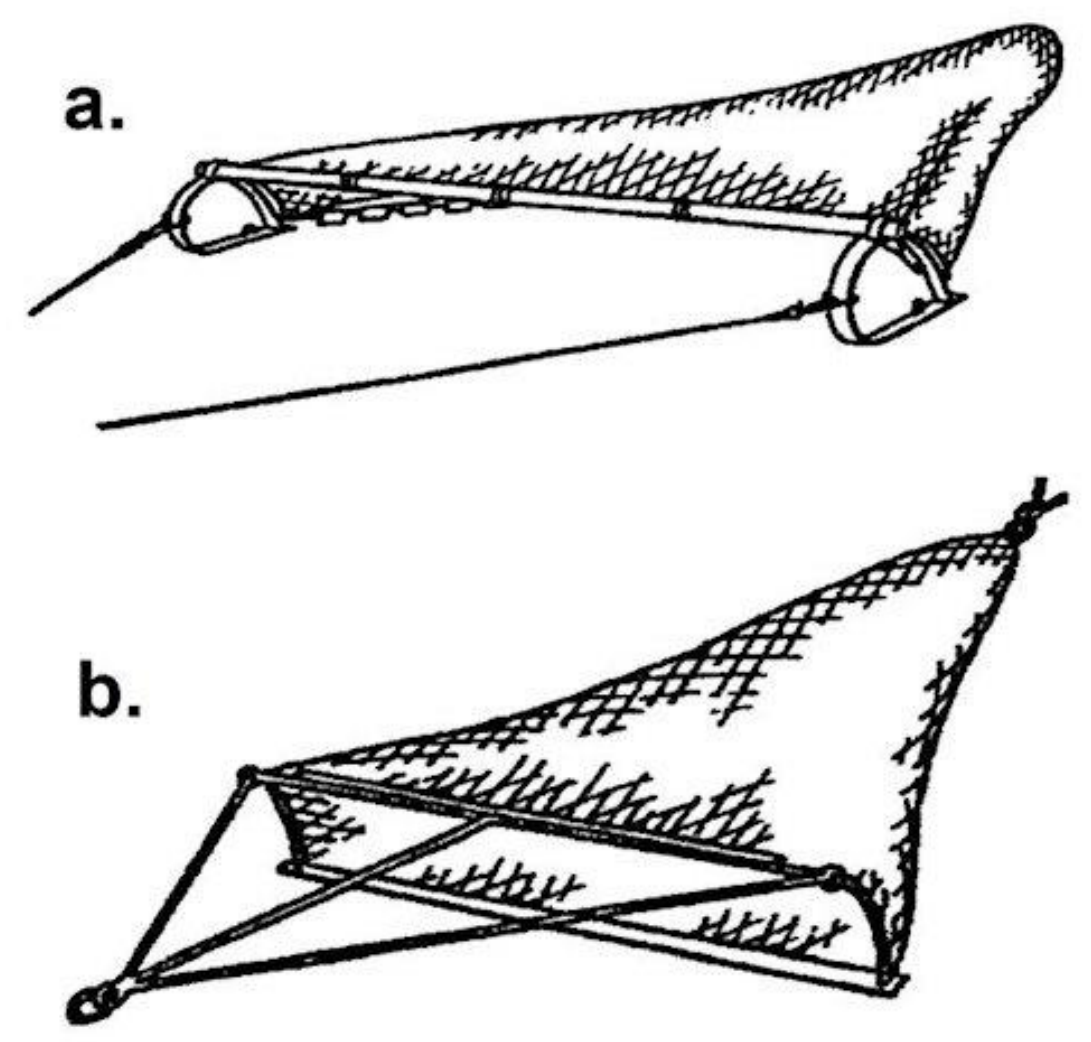

Figure 2: Types of bottom-fishing gear. (a): bottom-trawl of beam-type (b): dredge. (Image credit: after Nédélec and Prado 1990)

Bottom-fishing damages the sea-bed (Kaiser et al. 1996) and its occupants (Jenkins et al. 2001), including the whelks themselves (Mensink et al. 2000), contributing to their local extermination (Cadée et al. 1995). Therefore, the usual method uses 'pots' of woven wicker or wire, baited with dead fish or carrion (Hancock 1967, 4-6), much like 
fishing for crab or lobster. This method has been used for whelks for generations (e.g. Jeffreys 1867, 289-90).

Whelks are relatively uncommon in archaeological sites in North Atlantic Europe. They are infrequent in the region's Palaeolithic, Mesolithic and Neolithic shell-middens (Gutiérrez-Zugasti et al 2011; e.g. Dupont 2006; Thomas and Mannino 1999, 96) including the classic examples in Denmark (Andersen 2008; e.g. Nielsen 2008). Whelks were brought to sites far inland in the British Neolithic: a large perforated shell was found at Windmill Hill (Smith 1965, 135). They are found occasionally in later prehistoric deposits (Bell 1977, 287), in Roman towns (O'Connor 1986, 8) and rural settlements (e.g. Cartwright 1982, 25), in Viking-era settlements in northern Britain (e.g. Milner et al. 2007, 1466; O'Connor 1984), in later Saxon English towns (e.g. Winder 1980, 125) and coastal sites (e.g. Murray 2001), and in medieval towns (Campbell 2011, 5; O'Connor 1984). The recent recovery of a sizeable number of whelks from a single well-stratified deposit at a wellunderstood site (Carisbrooke Castle) meant those whelks merited detailed analysis.

\section{The Site}

\subsection{Introduction}

Carisbrooke Castle $\left(50^{\circ} 41^{\prime} 13.7^{\prime \prime} \mathrm{N}, 1^{\circ} 18^{\prime} 49.6^{\prime \prime} \mathrm{W}\right)$, on the Isle of Wight (Figure 3), is one of England's best-preserved castles (English Heritage 1995), with a well-understood history (Stone 1891) and archaeology (Young 2000). Begun soon after the Norman Conquest of England in AD 1066 as a motte-and-bailey castle on a steep-sided chalk hill previously used as a Saxon burh, the castle commands the central part of the Isle, which also has access to the sea by the long, narrow estuary of the River Medina. The motte-and-bailey had been converted into a stone shell-keep before a siege in AD 1136; the medieval domestic arrangements seen today were largely constructed in the mid-13th century (under Countess Isabella de Fortibus, who late in life reluctantly sold the castle to the English Crown). In the face of the threat of Spanish invasion of Tudor England at the end of the 16th century, the interior was 
altered to accommodate the residence of the Island's Captain (later Governor), and the whole of the medieval castle was surrounded by an essentially rectangular bastioned trace artillery fort.

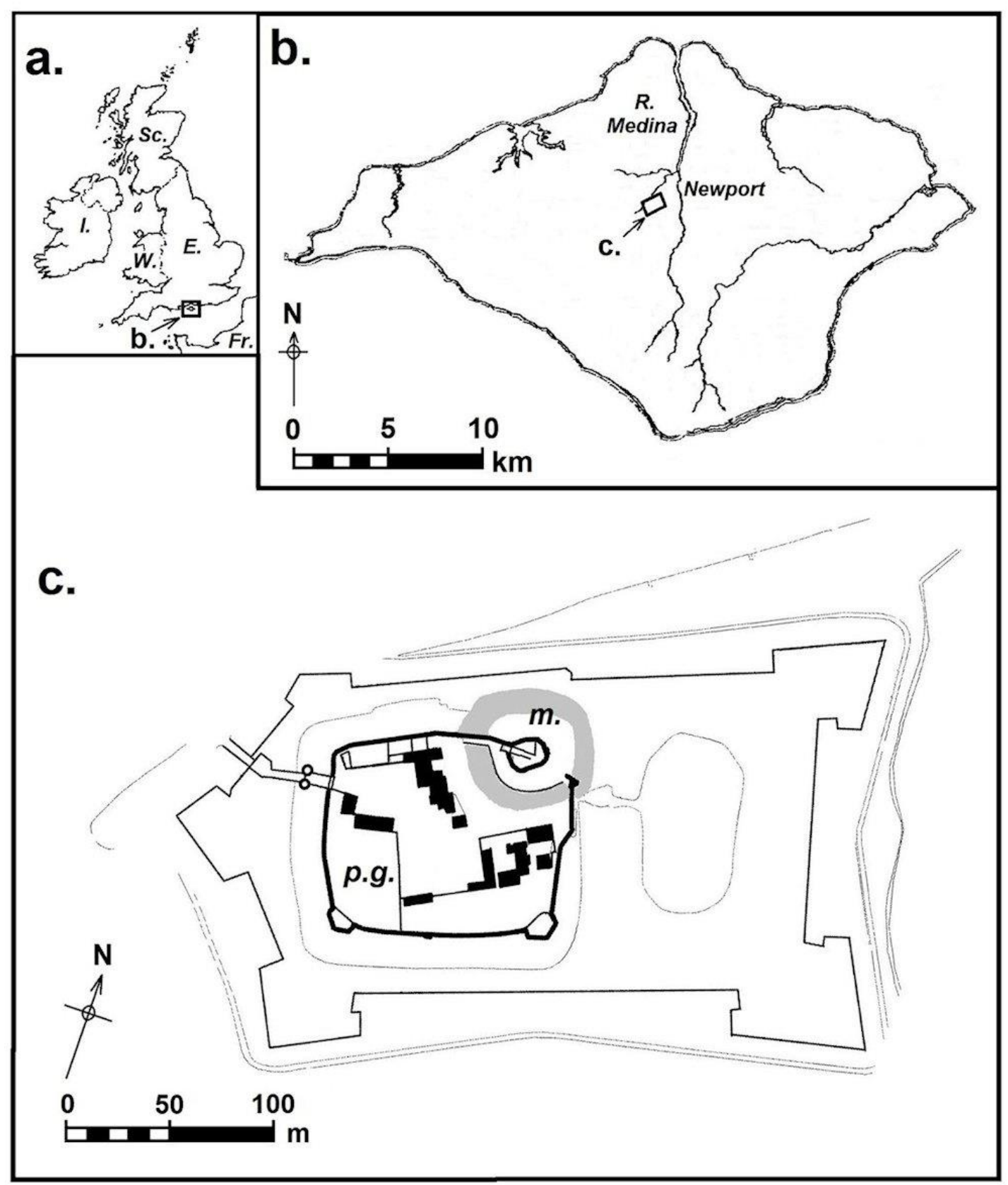

Figure 3: Location of the Isle of Wight, Carisbrooke Castle, and its Privy Garden.

(a): Britain and north-west France, showing location of Isle of Wight (b), England (E); Ireland (I); France (Fr); Scotland (S); Wales (W).

(b): Isle of Wight, showing location of Carisbrooke Castle (c.)

(c): Carisbrooke Castle with motte (m.) and Privy Gardens (p.g.)

The castle remained the defensive and administrative centre of the Isle until the mid-17th century, after its use at the end of the English Civil 
War as the prison for Charles I (Britain's last executed king). Practical government was transferred gradually to Newport, the Isle's principal town, at the head of the Medina estuary; the castle continued as the official residence of the Isle's Governor until the mid-20th century. The castle's below-ground archaeological remains are protected by law as a Scheduled Ancient Monument, and most of its structures are similarly protected as Listed Buildings (English Heritage 1995). The castle was taken into the care of the nation under the Office of Works in 1856, and has been managed as an ancient monument open to the public since 1944, currently by the nation's cultural heritage agency, English Heritage.

\subsection{The excavation}

During 2006 and 2008-9, eight small trenches were excavated by English Heritage archaeologists within the castle's Privy Gardens, in the southwest quadrant of the medieval castle (Figure 3c) under the direction of one of the authors (MR), to assess the impact on the archaeological remains of the area's reinstatement as a formal garden, to inform the design of this garden, and to enhance the understanding of the castle's history and development. This excavation (English Heritage Project 4992) revealed a previously unknown but large, high-status, stone-built cellared chamber-block built in the 12th century, extended during the 13th-14th centuries, kept and altered when adjacent structures were demolished in the 15th century, and finally razed to the ground late in the 16th century. A full report for the project will appear in the Proceedings of the Hampshire Field Club and Archaeological Society.

This small excavation produced numerous marine shells (Campbell 2013), comparable with sizeable urban excavations (e.g. Campbell 2011), supplementing the considerable numbers of shell-fish recovered in previous excavations at the castle, which included a small proportion of whelks (Wyles and Winder 2000). One of several kitchen-middens (context 7325) had accumulated against one of the walls of the chamberblock prior to its 16 th-century razing. It contained considerable roofing slate, ceramic building material, and edible marine molluscs such as oysters, whelks and cockles. It also contained 17 th-early 18 th century $A D$ pottery and a pipe bowl of $c$. AD 1730-1780 from its reworking as a garden soil, so it is safest to consider the whelks to have been discarded early in the modern period (the project's Phase 5). 


\section{The Whelks from Carisbrooke}

Kitchen-midden 7325 was relatively rich in whelks: the remains of at least 59 individuals were hand-retrieved. Whelk preservation was quite good: the four dimensions often measured on whelks (shell height, shell width, aperture height and aperture width) (Figure 4) were measurable or estimable to the nearest millimetre in 32 shells; post-depositional damage to the lip of the aperture in a further 16 meant only the shell height could be measured. Since archaeological whelks are uncommon, these whelks were subjected to full analysis along with most of the marine shells from the project (Campbell 2013). Statistical analysis of the measurements was performed with Version 1.91 of the statistical freeware, PAST (Hammer et al. 2001); results were considered significantly different from chance alone if the probability of a result was less than one in 20 $(P<0.05)$.

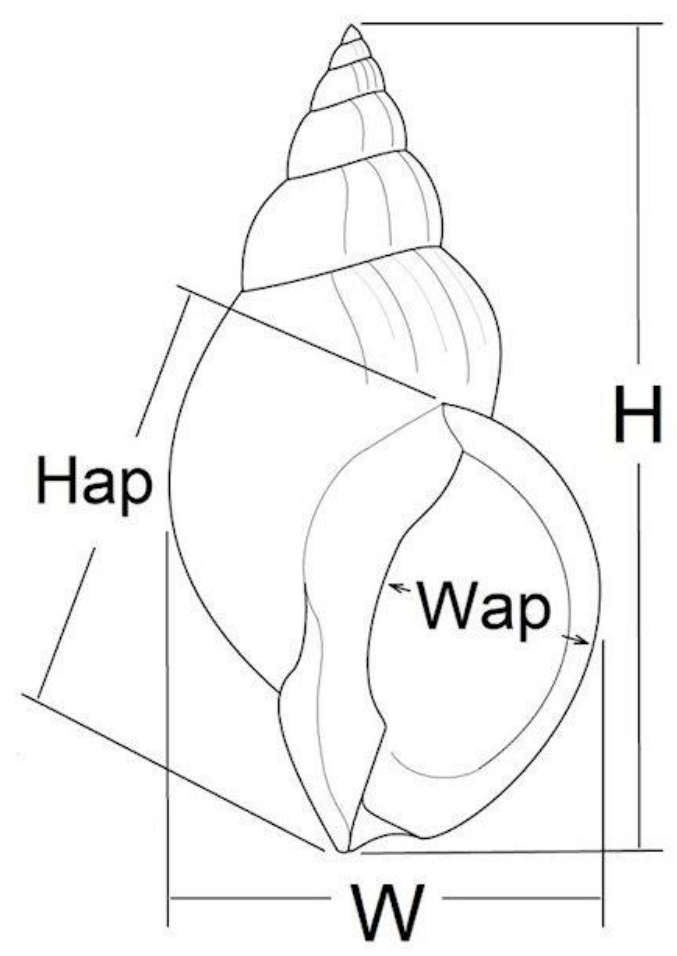

Figure 4: Dimensions (in $\mathrm{mm}$ ) measured on the intact whelks (B. undatum) in midden 7325 at Carisbrooke. H: shell height; Hap: aperture height; W: shell width; Wap: aperture width. (Image credit: after Thomas and Himmelman 1988). 


\subsection{Size}

Are these whelks of a size likely to have been consumed? Usually a whelk's size is measured by its shell height (e.g. Hancock 1967, 3). The smaller of these whelks were not more fragmented than the larger: the 16 more broken shells were not statistically different from the 32 intact shells in average shell height (Mann-Whitney $\mathrm{U}_{[31,15]}$ : 208.5; $P$ (same medians): 0.30 ) or shell height distribution (Kolmogorov-Smirnov test: $D_{[32,16]}: 0.281 ; P($ same distributions): 0.31$)$. Therefore the dimensions of the intact shells were a reliable sample of all the whelks.

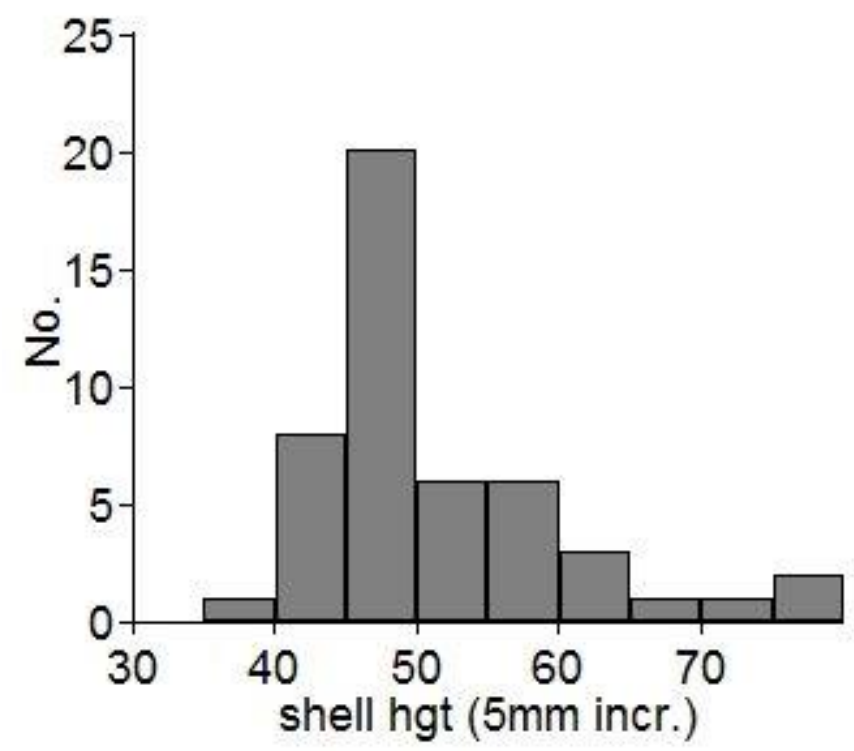

Figure 5: Distribution of shell height in the whelks from midden $7325(\mathrm{~N}: 48)$.

The intact and more-broken whelks combined had shell heights that ranged from $37.7-79.0 \mathrm{~mm}$ and averaged $51.4 \pm 9.1 \mathrm{~mm}$. The distribution of heights (Figure 5) was highly positively skewed (skewness statistic was 1.41 , and $15 \%$ were over $60 \mathrm{~mm}$ high). Whelks less than $40 \mathrm{~mm}$ were really not acceptable for harvest (only one was less than $40 \mathrm{~mm}$ ); this is not very different from the modern European legal landing size of $45 \mathrm{~mm}$ (EU 1998, 29). The sizes were similar to modern southern English whelks: those potted recently off Deal in Kent ranged from 31-89mm, averaging $54.3 \mathrm{~mm}$ (Shelmerdine et al. 2006, 2). 


\subsection{The type of sea-bed harvested for whelks}

Were these whelks all harvested from the same type of sea-bed, and (if so), what type? It is sometimes possible to use shapes of shells to assign them approximately to the place in the sea where they lived. An organism's shape varies with size (Gould 1966, 588). The stresses and strains on its body from physical forces in the environment vary with size because its weight, volume and surface area all alter with growth; therefore its body and its parts must alter in shape as the organism grows, to compensate for these changes in physical forces (McMahon 1975). Variation of shape with size in living things is termed allometry (Huxley 1932, 2), and its study has a considerable history (Gayon 2000). Marine molluscs, living an aquatic life, are inevitably subjected to fluid dynamics effects, which vary with size in complex ways (Vogel 1994, 87). Therefore marine molluscs usually grew allometrically, changing shape with size (Seed 1980), both in the present (Gaspar et al. 2002) and the past (Reitz et al. 1987). Since the typical pattern of environmental forces varies between habitats, the manner in which shape varies with size also tends to vary between habitats, even within a particular species of shell (e.g. Baxter 1983). If the manner in which shape varies with size is consistent within a sample of shells, they are likely to have all come from the same habitat.

The whelks from midden 7325 clearly exhibited allometric growth. The proportion of shell height to width $(\mathrm{H} / \mathrm{W})$ is sometimes employed to compare shapes between whelk populations (e.g. Thomas and Himmelman 1988, 227), but this ratio was not constant among the Carisbrooke whelks: it increased with size (Figure 6). When the relationship of the ratio $\mathrm{H} / \mathrm{W}$ with shell height is fitted by the standard regression technique (ordinary-least-squares regression: Sokal and Rohlf 1995,451 ), that relationship (the 'slope' of the line in Figure 6 ) was statistically very significantly greater than zero (slope: $0.0025 \pm 0.0009$; one-sample $t$-test: $t_{[30]}: 2.78 ; P($ no relationship): 0.0093 ). 


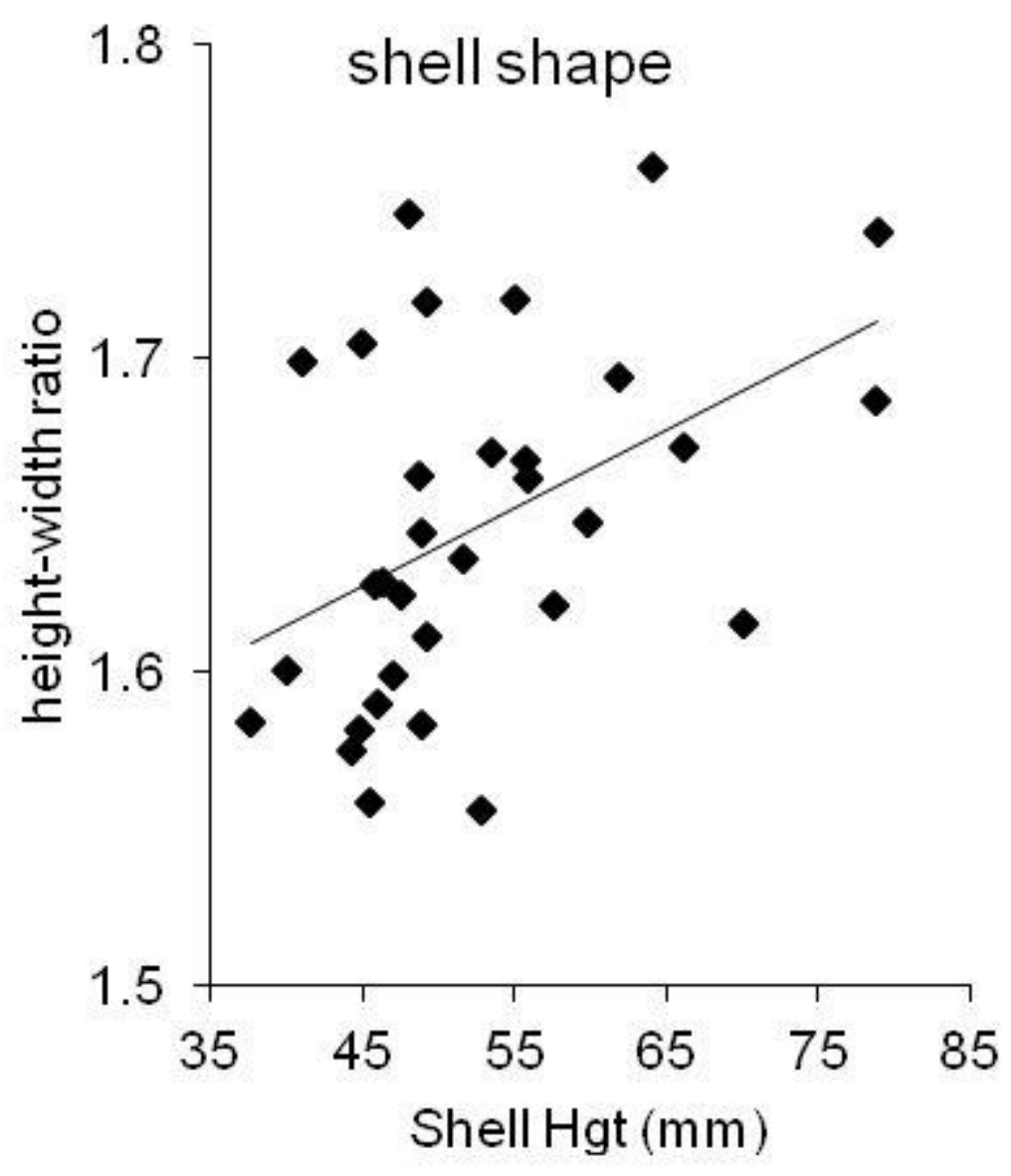

Figure 6: Variation of shell shape (height-width ratio, $\mathrm{H} / \mathrm{W}$ ) with shell size (shell height, $\mathrm{H}$ ) in the whelks in midden 7325 ( $N$ : 36). Line: linear regression fitted by o.l.s.

Usually, the relationship between any two dimensions $(x, y)$ of an organism is exponential $\left(y=\mathrm{A} x{ }^{\mathrm{b}}\right)$, the 'simple allometry' of Huxley (1932, 4-6). Relationships between dimensions are said to show 'isometry' if the exponent (b) is exactly one, and the ratio of two dimensions remains constant; the relationship is 'positively allometric' if (b) is more than one ( $y$ is growing faster than $x$ ), and 'negatively allometric' if (b) is less than one (Gould 1966, 594). If the relationship is not isometric, and proportions vary with size, graphs of the two dimensions are curved. Fitting linear relationships using linear regression techniques to allometric relationships can appear to produce good results (they can have values of Pearson's correlation statistic, $R$, quite near to one) but tend to over- or under-estimate in a systematic but complex way, and to produce results that are biologically nonsensical. For these whelks, using the standard linear regression technique (ordinary leastsquares linear regression) on the relationship of width with height produced a formula that initially appeared to be a good model $(R: 0.986)$ : 
$W(m m)=(2.92 \pm 0.93)+(0.551 \pm 0.017) \times(H)$

However, this linear model demands these whelks have a width before they exist: for a shell height of zero, the formula calculates shell width is typically $2.92 \mathrm{~mm}$, and insists, for a shell height of zero, a shell width of zero is extremely improbable (one-sample $t$-test: $t_{[30]}$ : $3.14 ; P(\mathrm{~W}=0)$ : $0.0038)$. Applying linear regression to whelk dimensions has produced similar bizarre results previously, indicating the relationships between dimensions were allometric (Thomas and Himmelman 1988, 227).

The exponential relationship between dimensions in 'simple' allometry becomes linear if the dimensions are transformed to their logarithms $(\log y=\log A+b \log x)$ (Huxley 1932, 4-6). Linear regression techniques (e.g. Sokal and Rohlf 1995, 451-83) can then be used to 'fit' a straight line to the data. The slope of the fitted straight line is the allometric exponent (b). The deviations of the points from the fitted line are used to estimate the standard deviation of the slope (b), its standard error (Sokal and Rohlf 1995,468$)$. Whether the relationship is isometric can then be determined by using a one-sample $t$-test (Sokal and Rohlf $\underline{1995}$, 227) to find the probability that (b) is exactly one, using its standard error.

The most common linear regression technique, ordinary least-squares (o.l.s.), is designed for prediction; it does not fit a line as closely as possible to the data (Sokal and Rohlf 1995, 453), which requires techniques called Model II regressions in biometry (Sokal and Rohlf $\underline{1995}$, 457; see Warton et al. 2006 for a review). The most commonly used Model II technique is reduced major-axis (r.m.a.) (Hammer and Harper 2006, 54), because it has few built-in assumptions about distributions and uncertainties (Sokal and Rohlf 1995, 544). Therefore linear regression with r.m.a. fitting was used to determine whelk shell allometry (by fitting a straight line to the relationship between the base10 logarithms of the shell dimensions, $\log _{10}(H)$ and $\log _{10}(W)$ ), and aperture allometry (using $\log _{10}$ (Hap) and $\log _{10}$ (Wap)).

The allometric relationship of shell width with height was estimated as $\log _{10}(W)=(-0.093 \pm 0.051)+(0.928 \pm 0.031) \times \log _{10}(H)$

This can be converted to give the estimate of the relationship in the original dimensions $(\mathrm{mm})$ : 
$W=(0.807 \pm 0.095) \times H^{(0.928 \pm 0.031)}$

The relationship was negatively allometric: the exponent $(0.928 \pm 0.031)$ was significantly less than one (one-sample $t$-test: $t_{[30]}: 2.32 ; P(b=1)$ : 0.027). Shell width tended to increase more slowly than height; the whelks tended to become relatively narrower as they grew.

All the whelks were well represented by this one allometric relationship. The impression given by the value for $R(0.984)$ being very near one can be tested further by examining the residuals (the regression-estimated value of a dimension minus its true value) for each individual in a sample (Draper and Smith 1981, 145-50). The residuals for width-height relationship in the original dimensions had a mean $(-0.03 \pm 0.97)$ that was clearly not significantly different from zero (one-sample $t$-test: $t_{[31]}$ : $0.031 ; P($ mean $=0): 0.97)$. Their distribution was not significantly different from normal $\left(X^{2}[31]: 1.75 ; P(\right.$ normal): 0.19$)$, and their relationship with predicted width showed no clusters or trend with size (Figure 7$)$.

The allometric relationship of aperture width and height was found to be $\log _{10}($ Wap $)=(-0.308 \pm 0.073)+(1.001 \pm 0.050) \times \log _{10}($ Hap $)$

or

Wap $($ in mm. $)=(0.492 \pm 0.083) \times \operatorname{Hap}^{(1.001 \pm 0.050)}$ 


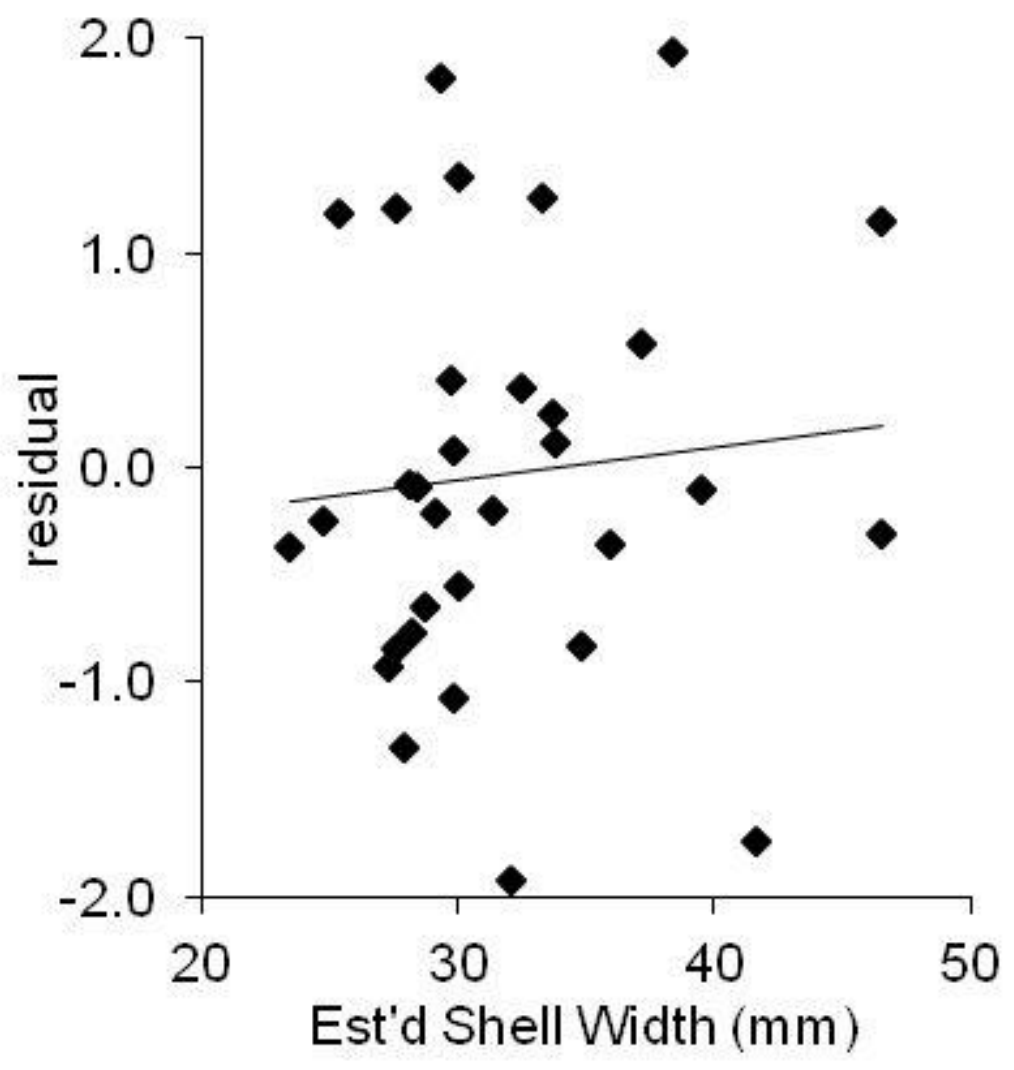

Figure 7: Relationship, with the estimated width values, of the residuals (estimated value, minus true value) in estimating shell width with the allometric formula for shell width derived for the whelks in midden 7325 (a 'versus plot') (N: 36). Line: linear regression fitted by o.l.s.

The aperture height-width allometry was isometric (the exponent was indistinguishable from one). The consistent aperture shape was confirmed by the ratio Hap/Wap, which averaged $2.03 \pm 0.10$. Unlike the shell height-width ratio (Figure 6), Hap/Wap was similar regardless of shell size (Figure 8): when the relationship of Hap/Wap with shell height was fitted using o.l.s. linear regression, that relationship (the 'slope' of the line in Figure 8 ) was clearly not significantly different from zero (slope: 0.00095 \pm 0.0018 ; one-sample $t$-test: $t_{[30]}: 0.53 ; P$ (no relationship): 0.60$)$. The Hap/Wap ratio seemed somewhat high compared with other whelks (e.g. Magnúsdóttir 2010,18), indicating narrow apertures, perhaps to thwart being eaten by crabs (Thomas and Himmelman 1988). 


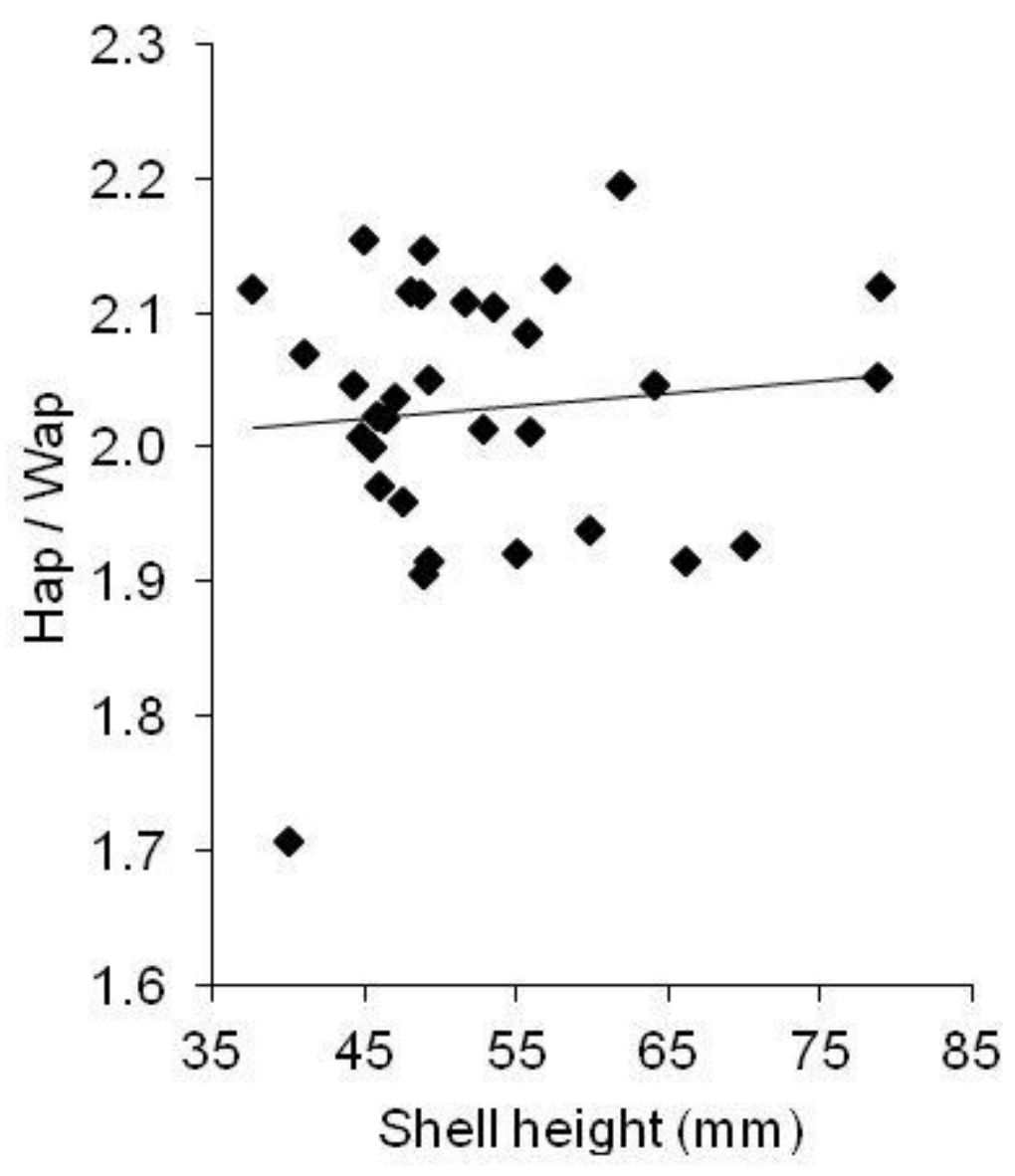

Figure 8: Relationship of aperture shape (Hap/Wap) with size (shell height) in the whelks from midden 7325 (N: 36); aperture shape does not change with shell size (cf. Figure 6). Line: linear regression fitted by o.l.s.

The shell morphology of the whelks demonstrated they are likely to have all been harvested from the same type of sea-bed. A single allometric relationship for both shell shape with size, and aperture shape with size, was a good characterisation of the shape and size of the individual whelks. Both allometric relationships were well characterised by the straight line, both values of $R$ were close to one, and there were no scatters or clusters in the residuals. Whelk shape is very variable, even within a single large bay (e.g. Magnúsdóttir 2010, 25-26), so the consistent relationships show all these whelks were harvested from a very similar habitat. Since these whelks likely came from the same sea-bed, they were probably all harvested at the same time. It remains safest to assume they were harvested and discarded during the reworking of the midden as an early modern garden soil, rather than when it accumulated during the medieval period. 
The allometric relationships showed the shells tended to become narrower with increasing size, but the aperture (through which the foot that attaches the whelk to the surface protrudes) kept a constant shape and grew in direct proportion with shell size. Keeping a foot in proportion with size as it increased suggests a need to remain attached, while making the shell narrower with size suggests a need for streamlining, so these whelks probably lived in fast or turbulent tidal flows, such as those known in the deeper parts of the channel north of Wight (Velegrakis 2000, 33).

\subsection{Damage}

Most of the whelks had unusual features on the lip of the aperture or (less commonly) to the outside of the last whorl (Figure 9). Damage could be slight: in ten whelks, a check in growth was marked by an abrupt step along the entire aperture, with the inner nacreous lining just visible on the surface (Figure 9a); four whelks had two or three such growth-checks followed by short periods of normal growth near the margin. Moderate damage was more common: in 15 whelks, the lip of the aperture had one or two cracks over $5 \mathrm{~mm}$ long, or a chip over $3 \mathrm{~mm}$ missing, but normal growth of the shell had resumed (Figure 9c). Damage could be severe: in 11 whelks, numerous cracks had propagated from the lip into the bodywhorl, and large fragments of the lip or body-whorl had been detached, and in some cases re-cemented into the shell by the living animal (Figure $9 e)$. Moderate or severe damage in the spire showed a whelk had survived damage when considerably younger (Figure 9g); 11 whelks had survived once before, seven had survived twice or three times, and one had survived four times; one unfortunate whelk had survived five episodes. 


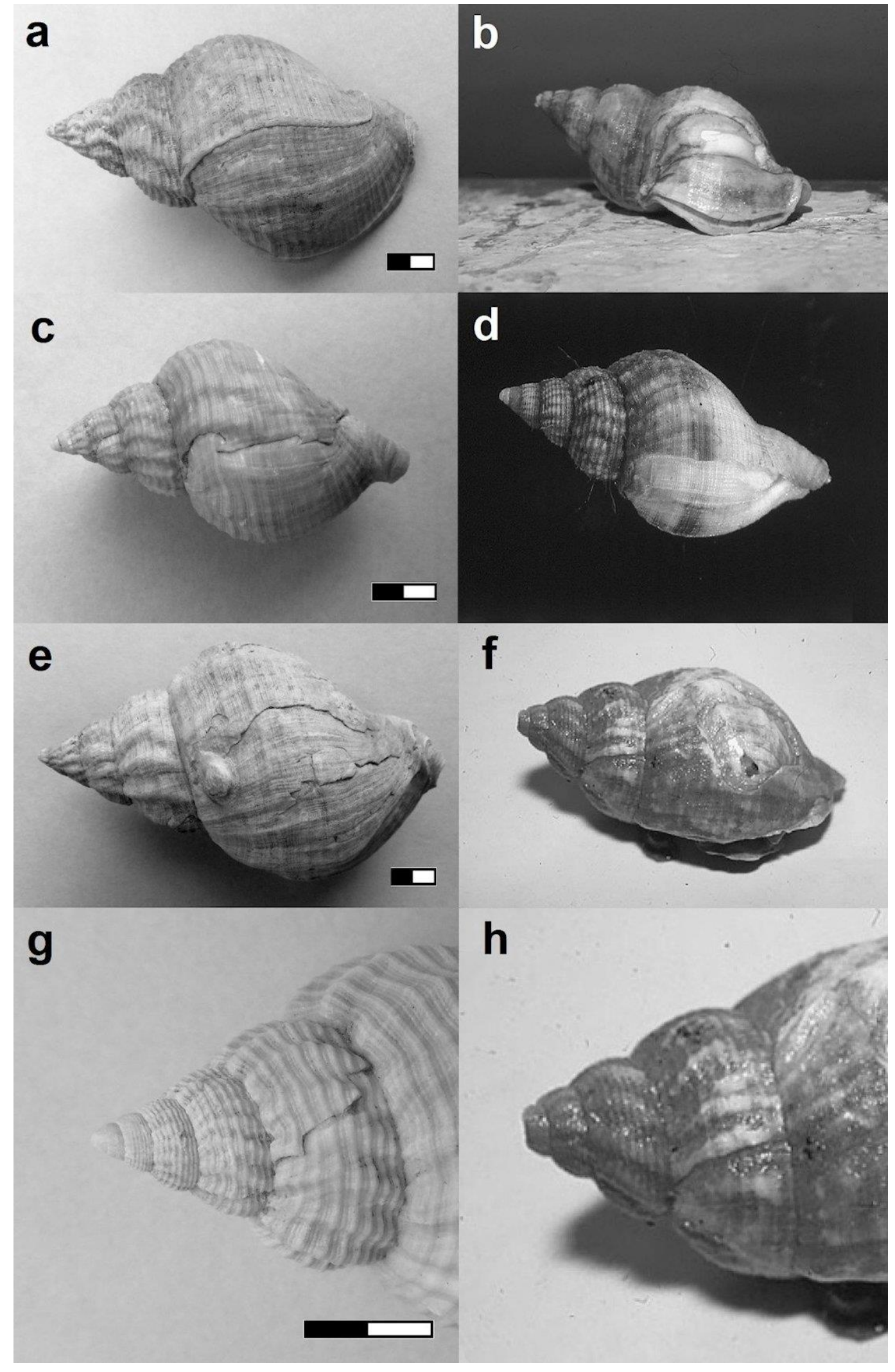

Figure 9: Examples of types of damage observed in archaeological whelk shells from Carisbrooke midden 7325 (a, c, e, g) and analogous damage in whelks beam-trawled from regularly trawled North Sea whelk beds (b, d, f, h; modified from figs 1 and 4 of Mensink et al. 2000). (a),(b): slight damage (growth-check to lip); (c),(d): moderate damage; (e),(f): severe damage to back of bodywhorl; $(\mathrm{g}),(\mathrm{h})$ : detail of spire showing repaired moderate or severe damage. Scale bar: $10 \mathrm{~mm}$. 
Repaired shell damage is characteristic of whelks subjected to intensive bottom-trawling (Cadée et al. 1995, 338), and analogous shell damage was done by bottom-trawling in modern whelks (Mensink et al. 2000, 56). While the slight damage could be caused by infection, attack by a predator, or some other trauma, it is common in bottom-trawled whelks (Figure 9b) (Mensink et al. 2000, 55). The moderate and severe types of damage are characteristic of bottom-trawling (Figs 9d, 9f), and absent in whelks harvested by potting (Mensink et al. 2000, 55). Repeated slight damage is also a feature of whelks that are regularly bottom-trawled (Figure 9h).

\subsection{Infestation}

Some of the whelks bore traces of marine organisms that had colonised their shells during life (Figure 10). Of the 48 shells intact or complete enough to measure shell height, one had been bored by the bristlewormPolydora ciliata (Figure 10a), two had bryozoan mats, one had a sand-worm tube, one had the calcareous byssus from the attachment of a saddle oyster (Anomia ephippium) (Figure 10b), one had infestation by the burrowing sponge Cliona (Figure 10c) and four had shells of juvenile oysters ('spat') (Figure 10d). Like oysters, the large solid shells of whelks are regularly infested by other marine organisms (Hancock 1967,4) and all these organisms had also infested oysters in the same deposit (Campbell 2013, 22). Oysters in the deposit had the oval form of regularly dredged deeper-water oysters (Campbell 2013, 22), and whelks are attracted to dead or damaged molluscs in areas damaged by bottomfishing (Ramsay et al. 1998), so these whelks had probably colonised a dredged deeper-water oyster bed. Infestation of whelks by oyster spat was unexpected, since spat tends to settle on stable surfaces, often among other oysters (Bayne 1969), and would tend to avoid settling on one of its predators. 


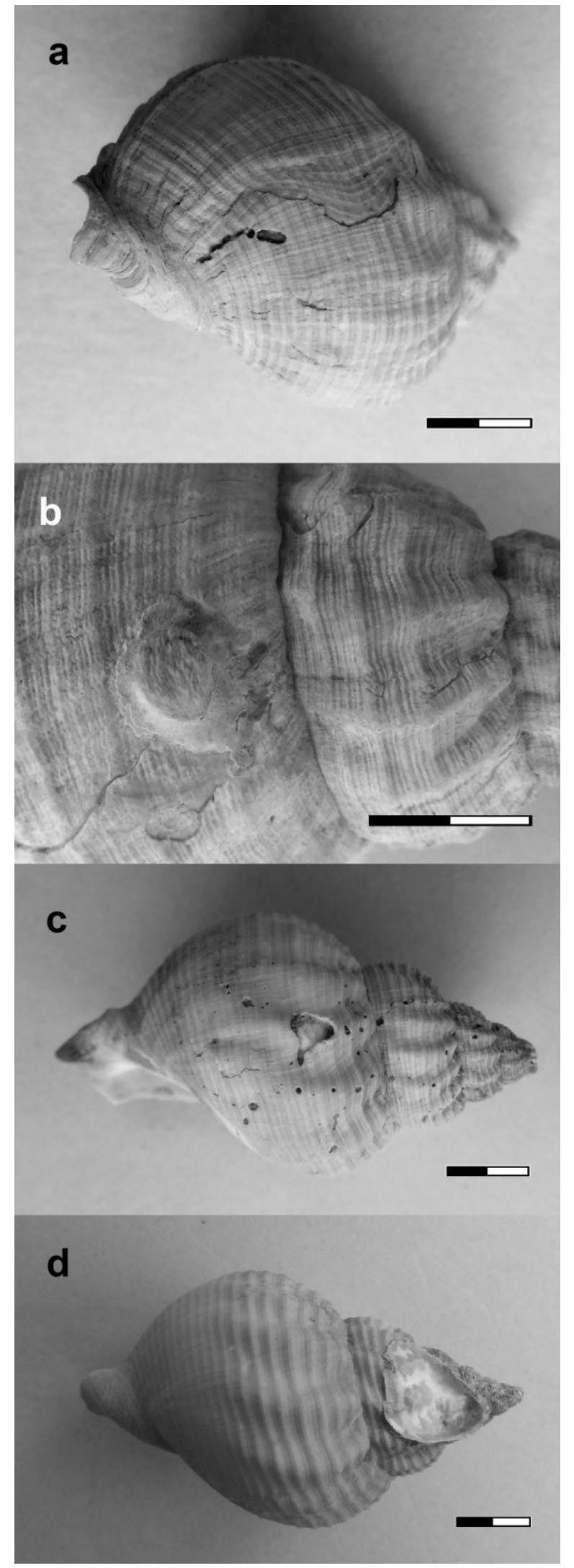

Figure 10: Examples of biological infestation of whelks from Carisbrooke midden 7325. (a): burrow of serpulid worm Polydora ciliata; (b): calcareous byssus from attachment of saddle-oyster Anomia ephippium; (c): linear pattern of surface perforations from the spongeCliona; (d): lower valve of juvenile oyster Ostrea edulis ('spat'). Scale bar: $10 \mathrm{~mm}$. 


\section{Conclusion}

These whelks were likely harvested by bottom-fishing. The size distribution was similar to that for modern southern English whelks. The very consistent size-shape relationships suggest they were all dredged from a similar habitat, probably in fast tidal flows. Their damage pattern is characteristic of trawling, and some were trawled repeatedly. It is also likely these whelks were dredged from a bed of oysters. The whelks were infested in a similar manner as many of the oysters in the same deposit, and the infestation included oyster spat, which tend to prefer other oysters.

This would appear to be the first archaeological instance of bottom-fishing for whelks being diagnosed via shell damage, and the first archaeological evidence for whelk harvesting being incidental to oystering. Direct evidence for bottom-fishing might be present in other archaeological shell-fish. Direct evidence was found in medieval oyster shells for harvesting with tongs (Dupont 2010). Damage as a result of trawling could not be differentiated from that due to natural causes in dog-cockles (Ramsay et al. 2001) or scallops (Schejter and Bremec 2007), but might be distinguishable in razor-clams (Gaspar et al. 1994). Bottom-fishing damaged carpet shells (venerids) but had little effect on Spisula, Donax or Mactra (Gaspar et al. 2002).

\section{Acknowledgements}

Thanks are due to the two anonymous reviewers of this paper whose comments improved the text, and to the Graduate School Human Development and Landscapes, Christian-Albrechts-Universität, Kiel, for funding the publication. 


\section{Bibliography}

Andersen, S.H. 2008 'Shell middens ("Køkkenmøddinger"): the Danish evidence' in A. Antczak and R. Cipriani (eds) Early Human Impact on Megamolluscs, Oxford: British Archaeological Reports Int. Ser. 1865, Oxford: Archaeopress. 135-56.

Barrett, J.H., Locker, A.M. and Roberts, C.M. 2004 'The origins of intensive marine fishing in medieval Europe: the English evidence', Proceedings of the Royal Society of London Series B 271, 2417-21. http://dx.doi.org/10.1098/rspb.2004.2885

Baxter, J.M. 1983 'Allometric relationships of Patella vulgata L. shell characteristics at three adjacent sites at Sandwick Bay in Orkney', Journal of Natural History 17, 743-55.

http://dx.doi.org/10.1080/00222938300770581

Bayne, B.L. 1969 'The gregarious behaviour of the larvae of Ostrea edulis L. at settlement', Journal of the Marine Biological Association of the United Kingdom 49, 327-56.

http://dx.doi.org/10.1017/S0025315400035943

Bell, M. 1977 'Resources of the seashore' in M. Bell 'Excavation at Bishopstone', Sussex Archaeological Collections 115, 285-87.

Beltrame, C. 2010 'Fishing from ships: fishing techniques in the light of nautical archaeology' in T. Bekker-Nielsen and D. Bernal Casasola (eds) Ancient Nets and Fishing Gear: Proceedings of the International Workshop on 'Nets and Fishing Gear in Classical Antiquity: A First Approach', Cádiz/Aarhus: Servicio de Publicaciones de la Universidad de Cádiz/Aarhus University Press. 229-42.

Cabral, J.P. and da Silva, A.C.F. 2003 'Morphometric analysis of limpets from an Iron-Age shell midden found in northwest Portugal', Journal of Archaeological Science 30, 817-29. http://dx.doi.org/10.1016/S03054403(02)00254-6

Cadée, G.C., Boon, J.P., Fischer, C.V., Mensink, B.P. and ten HallersTjabbes, C.C. 1995 'Why the whelk (Buccinum undatum) has become 
extinct in the Dutch Wadden Sea', Netherlands Journal of Sea

Research34(4), 337-39. http://dx.doi.org/10.1016/0077-

7579(95)90044-6

Campbell, G. 2008 'Beyond means to meaning: using distributions of shell shapes to reconstruct past collecting strategies', Environmental

Archaeology 13(2), 111-21.

http://dx.doi.org/10.1179/174963108X343236

Campbell, G. 2011 'Section 13: Marine molluscs' in B.M. Ford and S.

Teague (eds) Winchester, a City in the Making: Archaeological

Excavations between 2002-2007 on the sites of Northgate House, Staple

Gardens and the former Winchester Library, Jewry St, Oxford: Oxford Archaeology OA Library EPrints. Available:

http://library.thehumanjourney.net/663/11/Marine mollusc report.pdfA.p df. Last accessed 5 August 2014.

Campbell, G. 2013 Carisbrooke Castle, Isle of Wight: The Marine Shell from the 2006 and 2008/9 Evaluations, Portsmouth: English Heritage Research Report 42-2013.

Cartwright, C. 1982 'Aspects of the economy and environment of Bullock Down 4000 BC-AD 1550' in P. Drewett (ed) The Archaeology of Bullock Down, Eastbourne, East Sussex: The Development of a Landscape, Lewes: Sussex Archaeological Society. 8-38.

Dautzenberg, P. and Fischer, H. 1912 'Mollusques provenant des campagnes de l'Hirondelle et de la Princesse-Alice dans les Mers du Nord', Résultats des Campagnes Scientifiques Accomplies sur son Yacht par Albert Ier Prince Souverain de Monaco, Monaco: Imprimerie de Monaco.

Draper, N.R. and Smith, H. 1981 Applied Regression Analysis, Chichester: Wiley.

Dupont, C. 2006 La malacofaune de sites mésolithiques et néolithiques de la façade atlantique de la France: contribution à l'économie et à l'identité culturelle des groupes concernés, British Archaeological Reports Int.

Ser. 1571, Oxford: Archaeopress. 
Dupont, C. 2010 'A large-scale exploitation of oysters during the Middle Ages at Beauvoir-sur-Mer (France)', Munibe 31 (supplement), 188-98.

Engelhard, G.H. 2008 'One hundred and twenty years of change in fishing power of English North Sea trawlers' in A. Payne, J.R. Cotter and T. Potter (eds) Advances in Fisheries Science: 50 Years On from Beverton and Holt, Oxford: Blackwell. 1-25. http://dx.doi.org/10.1002/9781444302653.ch1

English Heritage 1995 'Carisbrooke Castle', National Heritage List for England. Available: http://list.english-

heritage.org.uk/resultsingle.aspx?uid $=1013870$ Last accessed 5 August 2014.

EU 1998 'Annex XII: Minimum sizes' in Regulation (EC) No. 850/98, Official Journal of the European Communities L 125 (27.4.1998), 28-29.

Eyton, T.C. 1858 A History of the Oyster and the Oyster Fisheries, London: van Voorst.

Fretter, V. and Graham, A. 1962 British Prosobranch Molluscs: Their Functional Anatomy and Ecology, London: The Ray Society.

Gaspar, M.B., Richardson, C.A and Monteiro, C.C. 1994 'The effects of dredging on shell formation in the razor clam Ensis siliqua from Barrinha, southern Portugal', Journal of the Marine Biological Association of the United Kingdom 74, 27-

938. http://dx.doi.org/10.1017/S0025315400043976

Gaspar, M.B., Leitão, F., Santos, M.N., Sobral, M., Chícharo, L., Chícharo, A. and Monteiro, C.C. 2002 'Influence of mesh size and tooth spacing on the proportion of damaged organisms in the catches of the Portuguese clam dredge fishery', ICES Journal of Marine Science 59, 1228-36. http://dx.doi.org/10.1006/jmsc.2002.1310

Gayon, J. 2000 'History of the concept of allometry', American Zoologist 40, 748-58. http://dx.doi.org/10.1668/00031569(2000)040[0748:HOTCOA]2.0.CO;2 
Gould, S.J. 1966 'Allometry and size in ontogeny and phylogeny', Biological Reviews 41, 587-640.

http://dx.doi.org/10.1111/j.1469-185X.1966.tb01624.x

Gutiérrez-Zugasti, I., Andersen, S.H., Araújo, A.C., Dupont, C., Milner, N. and Monge-Soares, A.M. 2011 'Shell midden research in Atlantic Europe:

State of the art, research problems and perspectives for the

future', Quaternary International 239, 70-

85. http://dx.doi.org/10.1016/j.quaint.2011.02.031

Hammer, Ø. and Harper, D.A.T. 2006 Paleontological Data Analysis, Oxford: Blackwell.

Hammer, Ø., Harper, D.A.T. and Ryan, P.D. 2001 'PAST: paleontological statistics software for education and data analysis', Palaeontologica Electronica 4(1). Available: http://palaeo-

electronica.org/2001_1/past/issue1_01.htm Last accessed 5 August 2014.

Hancock, D.A. 1967 Whelks, Burnham-on-Crouch, Essex: Ministry of Agriculture, Fisheries and Food Fisheries Laboratory Leaflet (New Series) 15.

Hayward, P.J. and Ryland, J.S. 1995 The Marine Fauna of the British Isles and North-West Europe II: Molluscs to Chordates, Oxford: Clarendon.

Hutchinson, G. 1994 Medieval Ships and Shipping, London: Leicester University Press.

Huxley, J.S. 1932 Problems of Relative Growth, London: Methuen.

Jeffreys, J.G. 1867 British Conchology IV: Marine Shells (In Continuation of the Gastropoda as far as the Bulla Family), London: van Voorst.

Jenkins, S.R., Beukars-Stewart, B.D. and Brand, A.R. 2001 'Impact of scallop-dredging on benthic megafauna: a comparison of damage levels in captured and no-captured organisms', Marine Ecology Progress Series 215, 297-301. http://dx.doi.org/10.3354/meps215297

Kaiser, M.J, Hill, A.S., Ramsay, K., Spencer, B.E., Brand, A.R., Veale, L.O., K. Prudden, K., Rees, E.I.S., Munday, B.W., Ball, B. and Hawkins, 
S.J. 1996 'Benthic disturbance by fishing gear in the Irish Sea: a comparison of beam trawling and scallop dredging', Aquatic Conservation 6(4), 269-85. http://dx.doi.org/10.1002/(SICI)10990755(199612)6:4<269::AID-AQC202>3.0.CO;2-C

Kent, B.W. 1992 Making Dead Oysters Talk: Techniques for Analyzing Oysters from Archaeological Sites, Crownsville, Maryland: Maryland Historical Trust.

McKee, E. 1983 Working Boats of Britain, London: Conway Maritime Press.

McMahon, T.A. 1975 'Allometry and biomechanics: limb bones in adult ungulates', American Naturalist 109, 547-

63. http://dx.doi.org/10.1086/283026

Magnúsdóttir, H. 2010 The common whelk (Buccinum undatum L.): Life history traits and population structure, Unpubl. MSc dissertation, Life and Environmental Sciences Faculty, University of Iceland, Reykjavik.

Mensink, B.B., Fischer, C.V., Cadée, G.C., Fonds, M., ten Hallers-Tjabbes, C.C. and Boon, J.P. 2000 'Shell damage and mortality in the common whelk Buccinum undatum caused by beam-trawl fishery', Journal of Sea Research 43, 53-64. http://dx.doi.org/10.1016/S1385-1101(00)00003-4

Milner, N. 2002 Incremental Growth of the European Oyster Ostrea edulis: Seasonality Information from Danish Kitchenmiddens, British Archaeological Reports Int. Ser. 1057, Oxford: Archaeopress.

Milner, N., Barrett, J. and Welsh, J. 2007 'Marine resource intensification in Viking Age Europe: the molluscan evidence from Quoygrew, Orkney', Journal of Archaeological Science 34, 1461-1472.

http://dx.doi.org/10.1016/j.jas.2006.11.004

Morales Muniz, A. 2010 'Inferences about prehistoric fishing gear based on archaeological fish assemblages' in T. Bekker-Nielsen and D. Bernal Casasola (eds) Ancient Nets and Fishing Gear: Proceedings of the International Workshop on 'Nets and Fishing Gear in Classical Antiquity: A First Approach', Cádiz/Aarhus: Servicio de Publicaciones de la Universidad de Cádiz/Aarhus University Press. 25-54. 
Murray, E. 2001 'Shellfish' in M. Gardiner, R. Cross, N. MacPherson-Grant and I. Riddler, 'Continental trade and non-urban ports in mid Anglo-Saxon England: excavations at Sandtun, West Hythe, Kent', Archaeological Journal 158, 261-64.

Nédélec, C. and Prado, J. 1990 Definition and Classification of Fishing Gear Categories, FAO Fisheries Technical Paper 222 (Revision 1), Rome: Food and Agriculture Organization of the United Nations. ftp://ftp.fao.org/docrep/fao/008/t0367t/t0367t00.pdf

Nielsen, N. 2008 'Marine molluscs in Danish Stone Age middens: a case study on Krabbesholm II' in A. Antczak and R. Cipriani (eds) Early Human Impact on Megamolluscs, British Archaeological Reports Int. Ser. 1865, Oxford: Archaeopress. 157-67.

O'Connor, T.P. 1984 Hand-collected molluscs from 16-22 Coppergate, York, London: Ancient Monuments Laboratory Report 4297.

O'Connor, T.P. 1986 Molluscs and other shell fragments from the General Accident Extension site, York (1983-4), London: Ancient Monuments Laboratory Report 4768.

Ramsay, K., Kaiser, M.J, and Hughes, R.N. 1998 'Responses of benthic scavengers to fishing disturbance by towed gears in different habitats', Journal of Experimental Marine Biology and Ecology 224(1), 73-89. http://dx.doi.org/10.1016/S0022-0981(97)00170-6

Ramsay, K., Richardson, C.A., and Kaiser, M.J. 2001 'Causes of shell scarring in dog cockles Glycymeris glycymeris L.', Journal of Sea Research 45(2), 131-139. http://dx.doi.org/10.1016/S13851101(01)00050-8

Rawson, K.J. and Tupper, E.C. 2001 Basic Ship Theory II: Ship Dynamics and Design, Oxford: Butterworth-Heineman.

Reitz, E.J., Quitmyer, I.R, Hale, H.S., Scudder, S.J. and Wing, E.S. 1987 'Application of allometry to zooarchaeology', American Antiquity 52(2), 304-17. http://dx.doi.org/10.2307/281782 
Robinson, G. 2013 '"A sea of small boats": places and practices on the prehistoric seascape of western Britain',Internet

Archaeology 34. http://dx.doi.org/10.11141/ia.34.2

Schejter, L. and Bremec, C. 2007 'Repaired shell damage in the commercial scallop Zygochlamys patagonica(King and Broderip 1832), Argentine Sea', Journal of Sea Research 58(2), 156-162.

http://dx.doi.org/10.1016/j.seares.2007.02.005

Seed, R. 1980 'Shell growth and form in the Bivalvia' in D.C. Rhoads and R.A. Lutz (eds) Skeletal Growth of Aquatic Organisms: Biological Records of Environmental Change, London: Plenum. 23-67. http://dx.doi.org/10.1007/978-1-4899-4995-0 2

Shelmerdine, R., Adamson, J., Laurenson, C. and Leslie, B. 2006 'Size variation in populations of the common whelk, Buccinum undatum', Port Arthur, Shetland: North Atlantic Fisheries College Marine Centre Fisheries Development Note 24. Available:

http://www.nafc.uhi.ac.uk/nafc/research/publications/fdn24 buckies web .pdf Last accessed 5 August 2014.

Smith, I.F. 1965 Windmill Hill and Avebury: Excavations by Alexander Keiller 1925-1939, Oxford: Clarendon.

Sokal, R.R. and Rohlf, F.J. 1995 Biometry: The Principles and Practice of Statistics in Biological Research, New York: Freeman.

Stone, P. 1891 The Architectural Antiquities of the Isle of Wight, London: by the author.

Thomas, M.L.K. and Himmelman, J.H. 1988 'Influence of predation on shell morphology of Buccinum undatumL. on the Atlantic coast of Canada', Journal of Experimental Marine Biology and Ecology 115, 22136. http://dx.doi.org/10.1016/0022-0981(88)90156-6

Thomas, K. and Mannino, M. 1999 'The bioarchaeology of the Culverwell shell midden' in S. Palmer (ed)Culverwell Mesolithic Habitation Site (Isle of Portland, Dorset): Excavation Report and Research Studies, British Archaeological Reports Brit. Ser. 287, Oxford: Archaeopress. 94-106. 
Valentinsson, D., Sjödin, F., Jonsson, P.R., Nilsson, P. and Wheatley. C. 1999 'Appraisal of the potential for a future fishery on whelks (Buccinum undatum) in Swedish waters: CPUE and biological aspects', Fisheries Research 42, 215-27. http://dx.doi.org/10.1016/S0165-7836(99)00050$\underline{8}$

Velegrakis, A. 2000 'Geology, geomorphology and sediments of the Solent System' in M.B. Collins and K. Ansell (eds) Solent Science - A Review. Proceedings of Solent Science Conference, Southampton, 29 September 2000, Amsterdam: Elsevier. 21-43.

Vogel, S. 1994 Life in Moving Fluids: the Physical Biology of Flow, Princeton, NJ: Princeton University Press.

Warton, D.I., Wright, I.J., Falster, D.S. and Westoby, M. 2006 'Bivariate line-fitting methods for allometry',Biological Reviews 81, 259-

91. http://dx.doi.org/10.1017/S1464793106007007

Winder, J.M. 1980 'The marine molluscs' in P. Holdsworth (ed) Excavations at Melbourne Street, Southampton, 1971-76, London: Council for British Archaeology Research Report 33. 121-27. http://dx.doi.org/10.5284/1000332

Winder, J.M. 1985 'Oyster culture' in G. Milne (ed) The Port of Roman London, London: Batsford. 91-96.

Winder, J.M. and Gerber-Parfitt, S. 2003 'The oyster shells' in G. Malcolm, D. Bowsher and R. Cowie (ed)Middle Saxon London: Excavations at the Royal Opera House 1989-99, London: Museum of London Archaeological Studies 15. 325-32.

Wyles, S.F. and Winder, J. 2000 'Marine molluscs' in C.J. Young (ed) Excavations at Carisbrooke Castle, Isle of Wight, 1921-1996, Salisbury: Wessex Archaeology Report 18. 185-88.

Young, C.J. (ed) 2000 Excavations at Carisbrooke Castle, Isle of Wight, 1921-1996, Salisbury: Wessex Archaeology Report 18. 